УДК 821.161.2-1.09

Крупка В. П.

кандидат філологічних наук, доцент кафедри української літератури, Вінницький державний педагогічний університет імені Михайла Коцюбинського

\title{
ВНУТРІШНІЙ СВІТ ДИТИНИ
}

\section{В ПОЕЗІї «МОНОЛОГ 3 МОГО ДИТИНСТВА» ДМИТРА ІВАНОВА}

У статті розкрито образ ліричного героя-дитини крізь призму реалій повоєнної дійсності. Драматичний модус художності, новелістична сюжетно-композиційна своєрідність, оповідність, монологічність мовлення дозволяють окреслити його почуття $i$ переживання, що сприяє цілісності розкриття изього образу.

Ключові слова: ліричний герой, наративність, монологічність, реципієнт, художня деталь, модус художності.

В статье раскрыто образ лирического героя-ребенка сквозь призму реалий послевоенной действительности. Драматический модус художественности, новеллистическая сюжетно-композиционная своеобразность, повествовательность, монологичность речи дают возможность проследить его чувства и переживания, что способствует иелестности раскрытия этого образа.

Ключевые слова: лирический герой, нарративность, монологичность, рециииент, художественная деталь, модус художественности.

The article analyzes the image of lyrical hero in the light of the realities of post-war reality. Dramatic modus of artistry, novelistic plot-compositional originality, narration, monologic speech 
allow to describe his feelings and emotions that promote the integrity of the disclosure of this image.

Keywords: lyrical hero, narration, monologue, recipient, artistic detail, modus of artistry.

Лейтмотивом творчості Дмитра Іванова - яскравого представника рустикальної лірики - $є$ українське село середини та другої половини ХХ століття у всій багатогранності художнього зображення. Митець слова на рівні проблематики, образної системи, поетики розкриває його драматичні сторінки у поколіннєвому зрізі, виписуючи яскраві буденні образи селян, вияскравлюючи їхній внутрішній світ.

У цьому аспекті ключовою є потенція текстових масивів його поезій, яка доводить, що образ ліричного героя максимально тотожний постаті автора в біографічному, світоглядному, інтенційному й ідіостильовому аспектах. А це дозволяє розглядати його художній світ, на думку Г. Сивоконя, крізь призму «ідентичного i доцільно багатогранного читання літератури як «текстобіографії» твору і творчості - не відчужених від особи творця, живої, цікавої, значної особистості, а, навпаки, трактованих у цілісності своїй i неповторності» [Сивокінь 1999: 14].

Драматизм, комізм, героїзм, трагізм як естетичні категорії узагальнюються як модуси художності. Як відзначає В.Тюпа, модус - «це та чи інша структура естетичної завершеності, яка передбачає не лише відповідний тип героя i ситуації, авторську позицію i читацьке сприйняття, але й внутрішньо єдину систему цінностей, і відповідну ій поетику» [ТЛ 2008: 55]. Домінантою, що об’єднує різнопланові складові художнього світу Дмитра Іванова, є щоденний драматизм, окреслений вихідною аксіомою повсякденного буття «ніщуо не минає, не лищаючи сліду, $i$ кожний крок - важливий для актуального та майбутнього життя», яка й обгрунтовує теоретичні аспекти драматичного модусу художності.

Тож мета розвідки - окреслення драматичної складової внутрішнього світу ліричного героя поезії «Монолог з мого дитинства», з’ясування природи його прагнень і вчинків. 
Внутрішня гострота поезії обумовлена іï виразною епічністю, наративністю, що дозволяє не лише через почуття i переживання ліричного персонажа, а й завдяки відповідним побутовим реаліям осягнути та осмислити драматичний модус художності його внутрішнього світу, окреслити повсякденні реалії «маленького» життя у повоєнній дійсності.

Це сприяє рецепції творчості автора в площині жанрових дефініцій балади. С. Тихолоз, досліджуючи домінанти художнього світу поета, вказує, що його балада «гармонійно поєднує в собі епічне й ліричне начало й передбачає у творі наявність розгорнутого й закінченого сюжету зі значною мірою емоційного напруження, тобто драматизму» [Тихолоз 2010: 93-94].

Визначальним його компонентом у поезії $\epsilon$ монологічність художньої оповіді, яка розкриває дитячу безпосередність ліричного героя. 3 цього приводу О. Яровий відзначає: «Звертаючись до теми дитинства, поет нітрохи не переграє, не вдає «дитячого сприймання», він його просто чітко пам’ятає. Він знов проживає оті кінокадри пам’яті. Саме проживає, не пригадує, не фантазує, не стилізує під «дитячість» [Яровий 2010: 562]. Відповідними характерними рисами відзначаються й автобіографічні вірші Д. Павличка, Б. Олійника, В. Симоненка, В. Забаштанського, П. Перебийноса та ін.

Безпосереднє переповідання персонажем Д. Іванова одного 3 епізодів дитинства, розкриття найсокровеннішого вводить реципієнта в художній світ повоєнних голодних реалій, де визначальними є особливо глибокі стосунки між дитиною і матір'ю:

Осінь скиртує тумани...

Я не за себе журюсь:

Ноги набрякли у мами,

Очі підпухли чомусь [Іванов 1983: 19].

Відвертість, одкровення в монолозі сприяє створенню уявного діалогу 3 читачем. Його сповідально-психологічна характеристика зумовлює привернення уваги не лише до зболених, проте якось мірою стриманих почуттів, а й до найменших життєвих деталей. Здавалося б, ліричний герой 
безпосередньо демонструє миттєвості свого дитинства, але перша його репліка, пов'язана 3 найдорожчою йому людиною. Вона розкриває хворобу матері. Тут драматизм набуває виразного внутрішнього вираження, обумовленого чутливістю, вмінням побачити те, що від героя намагаються приховати. Він акцентує увагу на тих дрібницях їхнього 3 матір'ю побуту, які створюють картину складного непривабливого повоєнного життя. Тісний зв'язок 3 найдорожчою людиною зумовлює прояв перших почуттів, турботи, відповідальності. Герой піклується про маму («Тільки б зігрітись матусі/ Під задубілим рядном») і зовсім по-дорослому (а може, то й репліки самого автора, віддаленого від свого героя висотою літ) говорить про іiі красу, можливо, не тільки тому, що їй потрібна підтримка, а й щоб утішитись самому:

Мамо, ви дуже красиві,

Гляньте в люстерко лишень.

То не синиі під очима,

То з большака пилюга,

Синя, немовби ожина,

Вам під повіки лягла [Іванов 1983:19].

Новелістична сюжетно-композиційна своєрідність вірша окреслює ще один штрих повоєнного дитинства, який хоча і є лише художньою деталлю, однак саме завдяки йому твір $\epsilon$ психологічно напруженим, реалістичним. Окреслений крізь призму світосприйняття ліричного героя концепт голоду реалізується побутовою подробицею «макуха»: «Ox $i$ смачненна ж макуха / в місті далекім росте / Мамо, я вас буду слухать, / Мамо... ще трішки дасте?» [Іванов 1983: 19].

Монолог ліричного героя лаконічно відображає дитячі пустощі, чуйність, перші дорослі почуття відповідальності. Хвороба матері зобов'язує героя до виважених вчинків, проте у душі він - дитина, - тому й окремі колізії життя сприймає крізь призму дитячого світобачення і світовідчуття («Я вже в плиту не залазив / В попелі грітись, i сам / Хату підмів, і ні разу / Босий в дворі не гасав» [Іванов 1983: 19]). 
Найвища драматична напруга у вірші створюється перш за все тим, що реципієнт здогадується, проте ще не до кінця розуміє: яке місце в сім’ї займає батько? Однак наступний хід поетичної оповіді уможливлює розкриття цієї деталі:

... A в mama

Я вже давненько не був.

Скучив за ними страменно! [Іванов 1983: 20]

Реалії повоєнного дитинства стають очевидними: хлопчик поспішає на цвинтар, де відразу знайде тата, бо «їхня могилка найвищза / у довжелезнім ряду». Тут, власне, i розкривається кульмінація твору, яка окреслює реальне/бажане ліричного героя, хоча про це автор нічого не говорить. Свідченням дитячого страждання $є$ тільки сльози, які він намагається приховати навіть тут, на кладовищі, бо тато може побачити: «A як зненац̧ька заплачу, / Щоб не побачили сліз, / Шапку насуну, неначе / Злізла сама аж на ніс» [Іванов 1983: 20]. Організуюча роль дитячого горя зближує драматизм із трагізмом, однак трагічне страждання визначається надособистісною виною, тоді як драматичне - особистою відповідальністю за своє зовнішнє життя, в якому герой невільний всупереч внутрішній свободі свого Я. Загалом треба відзначити, що дитячий біль не є тривалим, хлопчик швидко переключає увагу на інші сторони навколишньої дійсності. Найбільше його гріє думка, сконцентрована в художній деталі «B маминих чоботях тепло, / $B$ татовій шапияі - незгірш». Здавалося б, для дитини перших повоєнних літ нічого дивного немає, що вона саме так одягнена i взута. Проте саме ця художня деталь є свідчення зв’язку хлопчика зі своїми батьками (нехай, очевидно, 3 одним із них лише духовно). Любов найрідніших людей зігріває ліричного героя своїм теплом і радістю, від чого він знову оптимістично сприймає світ, заповнює цим усі свої помисли і вчинки.

Персонаж Д. Іванова тематично споріднений з дітьми і підлітками творів Г. Тютюнника, зокрема Павлушою з повісті «Вогник далеко в степу» і Климком 3 однойменної новели. Це представники того повоєнного покоління, до якого 
доля не була надто прихильною, i тому багатьом iз них швидко довелося подорослішати, відчути суворий драматизм життя.

Отже, драматичний модус художності визначає своєрідність дитячого внутрішнього світу в поезії Д. Іванова. У вірші «Монолог з мого дитинства» він розкривається крізь призму монологу ліричного героя, який окреслює усі почуття, переживання, порухи своєї юної душі. Реалізація цього типу модусу обумовлена побутовими реаліями, які, зрештою, i формують характер героя, a значить забезпечують цілісність художньої картини поетичного твору.

\section{БІБЛІОГРАФІЯ}

Брик 2008 - Брик О. Хіба примусиш серце замовчати / О. Брик // Сіверянський літопис. - 2008. - №4. - С. 163-167.

Іванов 1983 - Іванов Д. Заповіти мого роду : поезії / вступ. слово Б. Олійника / Дмитро Іванов. - К. : Рад. письменник, 1983. - 126 с.

Сивокінь 1999 - Сивокінь Г. «Самототожність письменника» як методологічна пропозиція / Григорій Сивокінь // Самототожність письменника : до методології сучас. літературознавства / відп. ред. Г. М. Сивокінь. - К., 1999. - C. 6-21.

ТЛ 2008 - Теория литературы : учеб. пособие для студ. филол. фак. высш. учеб. заведений : в 2 т. / под ред. Н. Д. Тамарченко. - Т. 1 : Н. Д. Тамарченко, В. И. Тюпа, С.Н. Бройтман. Теория художественного дискурса. Теоретическая поэтика. - 3-е узд., стер. - М. : Издательский центр, 2008. - 512 с.

Тихолоз 2010 - Тихолоз С. Голос обпеченого любов’ю серця : [рецензія на збірку поезій Дмитра Іванова «Село в терновому вінку»] / С. Тихолоз // Українська мова й література в середніх школах, гімназіях, ліцеях та колегіумах. - 2010. - № 2. - С. 92-102.

Тюпа 2002 - Тюпа В. Художественный дискурс (Введение в теорию литературы) / В. Тюпа. - Тверь : Твер. гос. ун-т, 2002. - 80 с. (Литературный текст : проблемы и методы исследования; Приложение, Серия «Лекции в Твери»). 
Яровий 2010 - Яровий О. Балади Дмитра Іванова : система життєвих цінностей героя / Олександр Яровий // Літературознавчі студії. - Вип. 26. - К. : Видавничий дім Дмитра Бураго, 2010. - С. 561-568. 